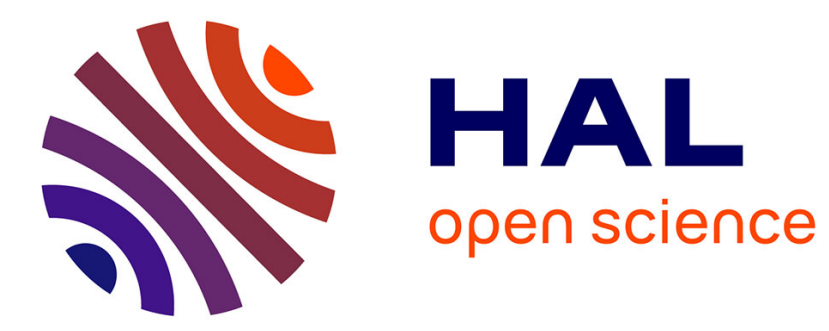

\title{
Diderot's views on artists' and inventors' rights : invention, imitation and reputation
}

Liliane Hilaire-Perez

\section{To cite this version:}

Liliane Hilaire-Perez. Diderot's views on artists' and inventors' rights : invention, imitation and reputation. British Journal for the History of Science, 2002, vol. 35, p. 129-150. hal-00695312

HAL Id: hal-00695312

https://hal-univ-paris.archives-ouvertes.fr/hal-00695312

Submitted on 7 May 2012

HAL is a multi-disciplinary open access archive for the deposit and dissemination of scientific research documents, whether they are published or not. The documents may come from teaching and research institutions in France or abroad, or from public or private research centers.
L'archive ouverte pluridisciplinaire HAL, est destinée au dépôt et à la diffusion de documents scientifiques de niveau recherche, publiés ou non, émanant des établissements d'enseignement et de recherche français ou étrangers, des laboratoires publics ou privés. 


\title{
Diderot's views on artists' and inventors' rights : invention, imitation and reputation
}

\author{
LILIANE HILAIRE-PÉREZ*
}

\begin{abstract}
This paper considers inventors' rights as revealing shifts in the elaboration of public trust in inventions. The two main issues, the method of invention and the credit invested, are analysed both in terms of Diderot's writings and in the economic, social and political context of invention during the eighteenth century. In a pamphlet written in 1755, Histoire et secret de la peinture en cire, Diderot criticized the Count of Caylus's attempt to keep the invention of wax painting secret and to enhance his fame thanks to this technical achievement. Diderot developed a conception of invention as an activity based upon methodical rediscoveries, imitations and translations. Although this could also concern artistic practice, imitation in art had a quite different meaning for Diderot. The main issue was the status of artists and inventors in society. Personal glory and private appropriation were denied to inventors, in contrast to artists. Secrecy, pride and exclusivity in invention were mean and ridiculous strategies. This was precisely what had been happening since the beginning of the eighteenth century, with the development of a market for inventions and exclusive titles, which also affected art. Diderot's narrative of invention as a daily, collective and historical process echoed the necessity of reassessing the value of invention by the criteria of public utility and shared evaluation.
\end{abstract}

Denis Diderot's fight for authors' rights is very famous. ${ }^{1}$ On the contrary, although paradoxical, the encyclopaedist's views on inventors' private rights and on technical invention are not so well known. There are several reasons: first, Diderot did not write much on this subject and, second, his conception of invention led him to deny any private intellectual property to inventors precisely at a time when inventors were fighting for social recognition and private rights. Diderot was rather in tune with the enlightened elites of the administration in opposing the private appropriation of techniques. Although Diderot celebrated technical inventivity, for instance in the article 'Art' of the Encyclopédie, there was a gap between what he claimed for authors and for artists, let us say for liberal arts, and what he denied to inventors, for the mechanical arts. We can approach this distinction thanks to some articles he wrote in the Encyclopédie ${ }^{2}$ and to a controversy in which

* Conservatoire national des arts et métiers, 292 Rue St-Martin, 75141, Paris, France. I am grateful to Natacha Coquery and Christine MacLeod for their comments and to Maxine Berg and Kate Scott for communicating unpublished papers.

1 J. Proust, 'Pour servir à une édition critique de la Lettre sur le commerce de la librairie', Diderot Studies (1961), 3, 321-45; R. Chartier, Les origines culturelles de la Révolution française, Paris, 1990, Chapter 3; J. Benoist, 'Introduction. Qu'est-ce qu'un livre? Création, droit et histoire' in I. Kant, Qu'est-ce qu'un livre?, Paris, 1995, 41-54.

2 D. Diderot and J. d'Alembert, Encyclopédie ou dictionnaire raisonné des sciences, des arts et des métiers, par une société de gens de lettres, 17 vols., Paris, 1751-65; idem, Recueil de planches sur les sciences, les arts libéraux et les arts mécaniques, avec leurs explications, 11 vols., Paris, 1762-72; for instance, the articles on 'Art', 'Academy', 'Brass', 'Eclecticism', 'Encaustic' (by Diderot or by Monnoyé) and 'Enamel'. 
Diderot played a major part through his pamphlet Histoire et secret de la peinture en cire (1755). ${ }^{3}$

This controversy concerned the claims of two artists, Jean-Jacques Bachelier and the Count of Caylus, to have invented a new paint based on encaustic (wax painting). What was at stake was their recognition as inventors, their rights to the invention and the intrusion of technical priority into the world of artistic fame and glory, since this new paint was exhibited in the Louvre (salon of 1755). ${ }^{4}$ Could an artist construct his fame on a technical invention, on a secret or even on a patent? ${ }^{5}$ This was an important question as artists were involved in a process of social distinction, trying to escape from the guilds and from the academies. ${ }^{6}$ Could technical practices and scientific study help artists' genius to be recognized or were they an obstacle? ${ }^{7}$ Although art could benefit from technical processes, although a painting was a narrative as well as an object made of linen, pigments, oil, varnish and wax, and although taste could appeal both to senses and to science, as Diderot thought and as antiquarians, collectors and archaeologists also believed, nevertheless, for Diderot, limits should be recognized and renegotiated.

There was also a strong pressure for the blurring of boundaries because of the development of luxury and semi-luxury trades based on aesthetic creativity, on exchanges between painters and manufacturers. Some entrepreneurs would enhance their fame and their business credit thanks to their association with artists, such as Josiah Wedgwood continuously inventing techniques and designs. ${ }^{8}$ In France, the painters Etienne Falconnet and François Boucher worked in the royal manufactury of Sèvres and the Lyonnaise

3 D. Diderot, L'Histoire et le secret de la peinture en cire, no place of imprint, undated, 103; idem, Euvres complètes (ed. R. Lewinter and Y. Beleval), 15 vols., Paris, 1969, ii, 782-824; idem, Euvres complètes (ed. J. Varloot), 27 vols., Paris, 1981, ix, 125-76.

4 D. Rice, 'The fire of the ancients: the encaustic painting revival, 1755 to 1812', Ph.D. dissertation, Yale University, 1979; idem, 'Jean-Jacques Bachelier et la redécouverte de la peinture encaustique', in Jean-Jacques Bachelier (1724-1806), peintre du roi et de Madame de Pompadour, Paris/Versailles, 1999, 67-74; idem, 'Encausting painting', in Dictionary of Art (ed. Jane Turner), New York, 1996, 196-200.

5 In a provocative way, the twentieth-century artist Yves Klein patented his blue colour (the 'Klein blue'); as an abstract painter, he wanted to desacralize the heroic and romantic status of painters by showing that art relied on technical practices, on skills and on tools. He was also convinced that materiality mattered more than shapes and lines. He was well aware that patenting a work of art was a major transgression.

6 N. Heinich, Du peintre à l'artiste. Artisans et académiciens à l'âge classique, Paris, 1993, Chapters 6 and 7; idem, 'De l'apparition de l' "artiste" à l'invention des "Beaux-arts", Revue d'bistoire moderne et contemporaine (January-March 1990) 37, 3-35; idem, 'Introduction' in E. Zilsel, Le génie. Histoire d'une notion de l'Antiquité à la Renaissance, Paris, 1993 (1st edition, 1926).

7 K. Scott, 'Authorship, the Académie, and the market in early modern France', Oxford Art Journal (1998), 21, 27-41; idem, 'Art and industry. A contradictory union: authors, rights and copyrights during the Consulat', Journal of Design History, forthcoming; idem, 'The colour of justice; the innovation and protection of colour printing in the XVIIIth century', in Pratiques historiques de l'innovation historicité de l'économie des savoirs, XVe-XXe siècle (ed. L. Hilaire-Pérez and A.-F. Garçon), conference of the CNAM, 21-3 March 2000), forthcoming; F. Rodari (ed.), Anatomie de la couleur. L'invention de l'estampe en couleurs, Paris and Lausanne, 1996; E. Lavezzi , 'Peinture et savoirs scientifiques. Le cas des Observations sur la peinture (1753) de Jacques Gautier d'Agoty', Dix-huitème siècle (1999), 31, 233-47.

8 C. MacLeod, Inventing the Industrial Revolution: The English Patent System, 1660-1800, Cambridge, 1988, 111; N. McKendrick, 'Josiah Wedgwood and the commercialization of potteries', in The Birth of a Consumer Society: The Commercialization of Eighteenth-Century England (ed. N. McKendrick, J. Brewer and J. H. Plumb), London, 1982, 100-45; E. Robinson, 'Matthew Boulton and Josiah Wedgwood, apostles of fashion', in Business 
designers were considered the 'soul' of the silk guild. ${ }^{9}$ Reference to artistic genius (and to authorship) was also used by inventors claiming exclusive rights on their works; others would build bridges between different kinds of property rights. ${ }^{10}$ Recognition of property rights was quickly evolving in trades mixing technical invention and artistic creativity. On the other hand, artistic creativity was benefiting from technical inventions and improvements such as pigments, enamels, processes for printing colour, sophisticated looms for patterned silks and miniaturization for neo-classical watches. ${ }^{11}$ In a very suggestive way, the painter Jean-Baptiste Huet, who designed calicos for the industrialist Oberkampf, created a whole set representing machines, tools and workers of the factory. ${ }^{12}$ Relations between art and industry were reinforced, exchanges enhanced and the process favoured, in parallel, by artists seeking reputation from technical inventions.

The main issue for Diderot was to explain that technical invention relied on a method, an 'art', which was not actually the case in artistic creativity $;{ }^{13}$ the crucial point was the understanding of the concepts of cumulation and imitation in the process of invention. ${ }^{14}$

in the Age of Reason (ed. R. P. T. Davenport-Hines and J. Liebenau), London, 1987, 98-114; M. Berg and H. Clifford, 'Commerce and the commodity: graphic display and selling new consumer goods in 18th-century England', in Art Markets in Europe, 1400-1800 (ed. M. North and D. Ormrod), Ashgate, 1998, $187-200$.

9 Musée Historique des Tissus, Soieries de Lyon Commandes royales au XVIIIe siècle (1730-1800), Lyon, 1988, 29. The same expression was used for calico designers; see S. Chassagne, Le Coton et ses patrons, 1760-1840, Paris, 1991, 277.

10 L. Hilaire-Pérez, L'Invention technique au siècle des Lumières, Paris, 2000, 175-88.

11 C. Velut, 'Décors de papier. Production, commercialisation et usages du papier peint à Paris, 1750-1820', Ph.D. dissertation, University of Paris-I-Sorbonne, 2001; A. Lajoix, 'La palette aveugle du céramiste', in Musée National des Techniques/Centre d'Histoire des Techniques, Muséologie technique, Journées d'études 1991-2, Paris, 1992, 71-6; H. T. Parker, The Bureau of Commerce in 1781 and its Policies with Respect to French Industry, Durham, 1979, 150-1; Musée Historique des Tissus, op. cit. (9), 18, 23, 56-60, 114; P. ArizzoliClémentel, Le Musée des Tissus de Lyon, Lyon, 1990, 76; Hilaire-Pérez, op. cit. (10), 76-7; Carolyn Sargentson, Merchants and Luxury Markets: The Marchands Merciers of Eighteenth-Century Paris, London, 1996, Chapters 3, 5; idem, 'The manufacture and marketing of luxury goods: the marchands merciers of late 17th- and 18thcentury Paris', in Luxury Trades and Consumerism. Studies in the History of the Skilled Workforce (ed. R. Fox and A. Turner), Aldershot, 1998, 99-137; G. Barber, 'The Parisian fine binding trade in the last century of the ancien régime', in ibid., 43-62; Lesley Ellis Miller, 'Paris-Lyon-Paris: dialogue in the design and distribution of patterned silks in the 18th century', in ibid, 139-67; J.-N. Ronfort, 'Art et horlogerie à l'époque de Ferdinand Berthoud: du rocaille au néo-classicisme’, in Musée International d'Horlogerie, Ferdinand Berthoud 1727-1807. Horloger mécanicien du Roi et de la Marine, La Chaux-de-Fonds, 1984, 103-27.

12 For the crossed methaphors between works of art and machines see A. Becq, 'La métaphore de la machine dans le discours esthétique de l'âge classique’, Revue des Sciences Humaines (1982-3), 186-7, 269-78; R. Démoris, 'Chardin, la machine et l'oiseau', in ibid., 292-306; H. Damisch, 'De la manufacture comme œuvre d'art économique à l'œuvre d'art comme machine', in ibid., 307-20.

13 Better known, but later, is the opposition made by Immanuel Kant between scientific inventivity and artistic genius: Kritik der Urteilskraft (1790), published in French as Critique de la faculté de juger (ed. Ferdinand Alquié), Paris, 1985, paragraph 46, 261-2.

14 On imitation and invention see J. Schlanger L'invention intellectuelle, Paris, 1983, 242-6; Sargentson, op. cit. (11), Chapter 4; Miller, op. cit. (11).; L. Hilaire-Pérez, 'Inventing in a world of guilds: the case of the Lyonnese silk industry in the XVIIIth century', forthcoming in Interiors, Decoration and Design: Essays in the History and Aesthetics of Material Culture in 18th-Century France (ed. K. Scott); M. Berg, 'French fancy and cool Britannia : the fashion markets of early modern Europe', in Proceedings of the Istituto Internationale di Storia Economica F. Datini (2000), 32, 1-36; idem, 'From imitation to invention: creating commodities in the eighteenth century', forthcoming in the Journal of British Studies; idem, 'Product innovation in core consumer industries in eighteenth-century Britain', in Technological Revolutions in Europe (ed. M. Berg and K. Bruland), London, 1998, 138-57; idem, 'New commodities, luxuries and their consumers in eighteenth-century England' in Consumers 
For Diderot, there existed a method of invention and this should entail neither any private property in knowledge nor fame, in contrast with artistic activity. Then again, artistic property and reputation should not be confused with patents. On one side was genius; on the other side was method. On one side there could be copyright, and even glory; on the other side, seeking recognition was a petty, ridiculous project and looking for property was an insult, a theft from humanity. What, then, could be the status of inventors in society?

We shall answer the question in three stages: first, how Diderot set up the controversy between the two painters; second, the philospher's conception of invention as a method, and third, his part in the enlightened reformation of the relationship between invention, credit and reputation.

\section{The narrative of a technique: the history and the secret}

In April 1755 Diderot published an anonymous pamphlet, Histoire et secret de la peinture en cire. Six months later, there was a salon in the Louvre where several painters exhibited paintings made with encaustic (wax painting). In both cases, techniques were involved in a display, rhetorical or visual. What did theses narratives mean? Did they aim at the same purpose?

As the title of Diderot's essay suggested, the text began with the narrative of the invention and it was followed by the description of the technical processes and materials involved. What was the purpose of this narrative, preceding the description? Did Diderot intend to set up a mythical story of creation? Heroization of inventors was not uncommon in mid-eighteenth-century France and the article on 'Invention' in the Encyclopédie (written by Louis de Jaucourt) would actually call forth this vision of invention..$^{15}$ Though this is one possible interpretation of Diderot's text, he mostly aimed at disclosing a technique; at the end of the pamphlet, there would be no more secrecy in wax painting. The term 'secret' was ironical, and 'histoire' too, like the whole pamphlet. If there was a history, this was not a tale but a historical account because invention was a historical process, embedded in a chronology of complex and daily operations. The narrative would explain how inventors invented, their method and their results, and this enquiry would be the only ground for crediting inventors and inventions. Legends and secrets were

and Luxury: Consumer Culture in Europe, 1650-1850 (ed. M. Berg and H. Clifford), Manchester, 1999, 63-85; H. Clifford, 'Concepts of invention, identity and imitation in the London and provincial metal-working trades, 1750-1800', Journal of Design History (1999), 12-3, 241-55; E. Homburg, 'From colour maker to chemist: episodes from the rise of the colourist, 1670-1800', in Natural Dyestuffs and Industry in Europe 1750-1880 (ed. R. Fox and A. Nieto-Galan), Watson, Canton, 1999, 219-58; A.-F. Garçon, Mine et métal, 1780-1880. Les nonferreux et l'industrialisation, Rennes, 1998, 32-3.

15 Hilaire-Pérez, op. cit. (10), Chapter 4. For the heroization of inventors in England in the nineteenth century see C. MacLeod, 'James Watt, heroic invention and the idea of the Industrial Revolution', in Consumers and Luxury: Consumer Culture in Europe, 1650-1850 (ed. M. Berg and H. Clifford), Manchester, 1999, 96-116; idem, 'L'invention héroïque et la première historiographie de la révolution industrielle', in Pratiques historiques de l'innovation historicité de l'économie des savoirs, XVe-XXe siècle (ed. L. Hilaire-Pérez and A.-F. Garçon), conference of the CNAM, 21-3 March 2000), forthcoming. Concerning inventors' fame in previous periods see Pamela O. Long, 'Invention, authorship, "intellectual property", and the origin of patents: notes toward a conceptual history', Technology and Culture (1991), 32, 846-84; idem, Openness, Secrecy, Authorship: Technical Arts and the Culture of Knowledge fom Antiquity to the Renaissance, Baltimore, 2001. For a philosophical approach of myths of invention, see Schlanger, op. cit. (14), Chapter 1. 
usurpations of identity and perversion of public trust. This was at the core of the controversy which Diderot set up by opposing Bachelier to Caylus.

The artist Jean-Jacques Bachelier (1724-1806) was the main protagonist in Diderot's pamphlet. He had been a member of the Académie royale de peinture since 1750 and the artistic director of the royal manufactury of porcelain in Vincennes since 1752 (then at Sèvres in 1756). ${ }^{16}$ In 1766 he would create the Ecole royale gratuite de dessin, a project Diderot had also conceived and which came in the wake of several attempts to reform technical training (Bachelier's school will become the Ecole nationale des arts décoratifs). ${ }^{17}$ The second character was Anne-Claude-Philippe de Caylus (1692-1765). He was an aristocrat, well established in Parisian coteries, such as that of Samuel Crozat (a financier and collector). ${ }^{18} \mathrm{He}$ also was a member of the Académie royale de peinture, where he tried to revivify historical painting and to develop interest in antiquity. Actually, he was more famous as an antiquarian, a collector and a founder of a new discipline, archaeology; he had made discoveries in Herculaneum and Pompeii $(1738,1748)$ and he was the theoretician of archaeology as a cognitive science. ${ }^{19}$ At the time of the controversy with Diderot, he was publishing the seven volumes of the Recueil d'antiquités égyptiennes, étrusques, romaines et gauloises. In the Republic of Letters, he was a crucial character, a powerful academician and a rival for Diderot's fame. ${ }^{20}$

According to Diderot, Bachelier was the first discoverer of one process for melting colours and wax with turpentine, by chance, in 1749 , but Caylus was the first to have informed the public, in the Académie de peinture (1753) and then in the Académie des inscriptions et belles-lettres and in Marie-Thérère Geoffrin's salon where he presented a wax painting, made by Joseph-Marie Vien (Head of Minerva, 1754). Caylus's initiative was emphasized by an article in the Mercure de France. It wounded Bachelier's pride and led him to improve his process with an alkali solution and the heating of the painting afterwards. For Diderot, this heating was very near to Pliny's description; it was the authentic encaustic of the ancients (wax painting and use of heat). Moreover, Bachelier was prompted by this competition to read Pliny the Elder ${ }^{21}$ where he discovered the process of Apelle's varnish, also with alkaline encaustic. Reference to antiquity and quest for authenticity was crucial for establishing Bachelier's status as the inventor, instead of

16 H. Mouradian and X. Salmon, 'Biographie et étude de l'œuvre de Jean-Jacques Bachelier', in Jean-Jacques Bachelier (1724-1806), peintre du roi et de Madame de Pompadour, Paris/Versailles, 1999, 13-50; Simon Lee, 'Bachelier, Jean-Jacques' in Dictionary of Art (ed. Jane Turner), New York, 1996, 19.

17 A. Léon, La Révolution et l'enseignement technique, Paris, 1968, 45-6, 48-9, 55-6, 70, 245; idem, 'Une forme typique de l'enseignement technique à la fin du XVIIIe siècle: les écoles de dessin', Bulletin du C.E.R.P. (1963) 12, 67-9; Y. Deforge, Le graphisme technique. Son enseignement et son histoire, Seyssel, Champ Vallon, 1981, 170-2; U. Leben, 'Jean-Jacques Bachelier et l'Ecole royale gratuite de dessin', in Jean-Jacques Bachelier (1724-1806), peintre du roi et de Madame de Pompadour, Paris/Versailles, 1999, 75-85; for other references see Sargentson, op. cit. (11), 59.

18 D. Rice, 'Caylus, Comte de', in Dictionary of Art (ed. Jane Turner), New York, 1996, 120-1.

19 A. Schnapp, 'De Montfaucon à Caylus: le nouvel horizon de l'Antiquité', in La fascination de l'antique 1700-1770. Rome découverte, Rome inventée, Lyon/Paris, 1998, 142-5.

$20 \mathrm{~K}$. Pomian, 'Médailles/coquilles = érudition/philosophie' in idem, Collectionneurs, amateurs et curieux. Paris-Venise: XVIe-XVIIIe siècle, Paris, 1987 (1st edition 1978), 142-62, 155-62.

21 Diderot, op. cit. (13), 815-6. Diderot refers to Pliny's Natural History, Book XXXV, Chapter X. For a recent edition see Histoire naturelle, Livre XXXV (tr. and ed. Jean-Michel Croisille), Paris, 1985. 
Caylus who, as an antiquarian, also claimed to have rediscovered encaustic paint after translating Pliny. Bachelier was also open-minded, according to Diderot, whereas Caylus had kept his discovery secret to enhance his reputation and distinction among artists, academicians and amateurs.

The antipathy of Diderot for Caylus, whom he had met in the same circle (Mme Geoffrin's), was then being expressed in a new light; Diderot had found new weapons for competing with and mocking Caylus, especially in Caylus's realm, antiquity. As Danielle Rice has demonstrated, Bachelier was an instrument in Diderot's strategy for assaulting Caylus's fame and influence. In the elite world of Paris and other European capitals, defenders and opponents of each painter soon appeared; pamphlets, articles and letters were published and the writings were always very polemical, acid and satirical. Caylus could not continue much longer to conceal his technique. He published a detailed memoir in August $1755 .^{22}$ The controversy reached a climax in the Louvre exhibition at the end of 1755 and it was immediately recorded in the article on 'Encautisc' of the Encyclopédie (t. V) (either by Diderot or Monnoyé), in November 1755. Technical invention (actually, a rediscovery from antiquity) was fostering competition between painters and this was what Diderot and the Encyclopaedists were opposing in their fight against the social domination of amateurs and academicians who intended to guide taste and genius by grounding art upon knowledge, techniques, rules and models. ${ }^{23}$

\section{Exhibiting techniques}

As an academic painter, Bachelier was used to exhibitions in the salons and he chose this means to expose his newly invented material in a painting called The Fable of the Wolf and the Horse at the 1755 exhibition in the Louvre. ${ }^{24}$ The subject was inspired by La Fontaine and it belonged to animalistic style and narrative painting, the highest styles in the academic hierarchy, unlike nature morte (still-life painting) or bouquet (flowers). ${ }^{25}$ Bachelier, who was only a flower painter in the Académie, was aiming to enter a career of honour thanks to this painting. The size of the canvas was gigantic too ( 3.5 meters by 2.7 meters). Both the narrative of the painting and its technical composition aimed at seeking recognition in the academic world, where Caylus had so much influence.

The colours of the painting had been mixed with an alkaline solution of wax ('lessive', 'ean de cire' in Diderot's words) and at the end of his work, the artist had heated the surface of the painting near a fire to fix the colours and harden the texture ('inustion'), which necessitated much skill not to burn the painting (this had happened to Joseph-Marie Pierre). Bachelier also exhibited three other paintings made with wax but the technical process was different for each. For instance, in one of them, the colours had been mixed with wax dissolved in turpentine; in another, the painting had been heated on the reverse side.

22 A.-C.-P. de Caylus, Mémoire sur la peinture à l'encaustique et sur la peinture en cire, Puteaux, Erec, 1999 (1st edition 1755).

23 Pomian, op. cit. (22), 155-62.

24 Though the painting has disappeared, there was one copy made in 1761; all following information on Bachelier comes from D. Rice's works, cited above.

25 Heinich, Du Peintre, op. cit. (6), 137-47. 
Bachelier was not the only painter to exhibit technical prowess in the Louvre. Vien presented six paintings made with encaustic, Alexandre Roslin presented one and LouisJoseph Le Lorrain two. These three painters were famous and they belonged to the coterie patronized by Caylus. The different paintings in the Louvre were proofs and display of the archaeologist's rediscovery, especially his Head of Minerva. With the help of Vien and of a chemist, Majault, Caylus had achieved a melting of wax and colours in a tin-plate case on boiling water and he had covered the plank with pure wax (before painting), what he called his first process in his memoir. Then, he had heated the painting with the help of a portable burner, described as his second process, and he had applied a varnish made with turpentine. $^{26}$

In the Louvre, then, there were actually thirteen paintings making use of several different processes and the 'Caylus-Vien' painting itself combined different techniques. The presentation of all these technical achievements transformed the 1755 Louvre exhibition into an experimental forum for rediscovering encaustic paint and for presenting new uses of it (it was a 'terrain d'essa', in the words of Rice). There was a whole collection of processes based on a complex range of substitutions and adaptations. This technical diversity also meant competition between painters, more precisely between Bachelier and Caylus. In the article on 'Encaustic' of the Encyclopédie, the Fable was interpreted as Bachelier (the horse) knocking down Caylus (the wolf). On the one hand, the collection was an assortment of techniques, closely related but different; it could open the way to comparisons and further improvements. It was emblematic of a whole process of invention, as a narrative of imitation. On the other hand, techniques were involved in a spectacular enterprise of persuasion where fame in coteries and artistic reputation were the main prizes.

As in the house of the Society of Arts instituted in London in 1754, where an exhibition of paintings and a repository of inventions cohabited in the same building, boundaries blurred between arts and crafts. ${ }^{27}$ The refinement of display in shops with large glass windows was also part of this process. ${ }^{28}$ If this could enhance the reputation of technical achievements, in a symmetrical way, fame in painting could profit from a technical prowess and from the rhetoric of technology. Caylus's plates in his memoir were illustrative of these

26 The Head of Minerva might have been finished with a turpentine varnish according to the Encyclopédie; see below.

27 D. G. C. Allan, William Shipley, Founder of the Royal Society of Arts: A Biography with Documents, London, 1979 (1st edition 1968), 72. See also Mme de Genlis's 'musée-bijou', a luxurious exhibition of technical models in the Palais-Royal for the education of the Duke of Chartres's children and then for public display; J. Payen, Capital et machine à vapeur au XVIIIe siècle. Les frères Périer et l'introduction en France de la machine à vapeur de Watt, Paris, 1966, 49-53.

28 Sargentson, op. cit. (11), Chapter 6; C. Walsh, 'Shop design and the display of goods in eighteenth-century London', Journal of Design History (1995), 8, 157-76; G. Blake-Edwards, 'Wedgwood's Dublin showroom', Journal of the Royal Society of Arts (1990), 138, 840-3; C. Velut, 'Le monde interieur de la boutique: les boutiques de papiers-peints à Paris, 1750-1820', in La Boutique et la ville. Commerces, commerçants, espaces et clientèles XVIe-XXe siècle (ed. N. Coquery), Tours, 2000, 277-94; O. Dautresme, 'Du Palais-Cardinal à "l'enceinte magique": la représentation du Palais-Royal dans les guides de Paris aux XVIIe et XVIIIe siècles' in Les Guides imprimés du XVIIe au XXe siècle. Villes, paysages, voyages (ed. G. Chabaud, E. Cohen, N. Coquery and G. Penez), Paris, 2000, 391-402. 

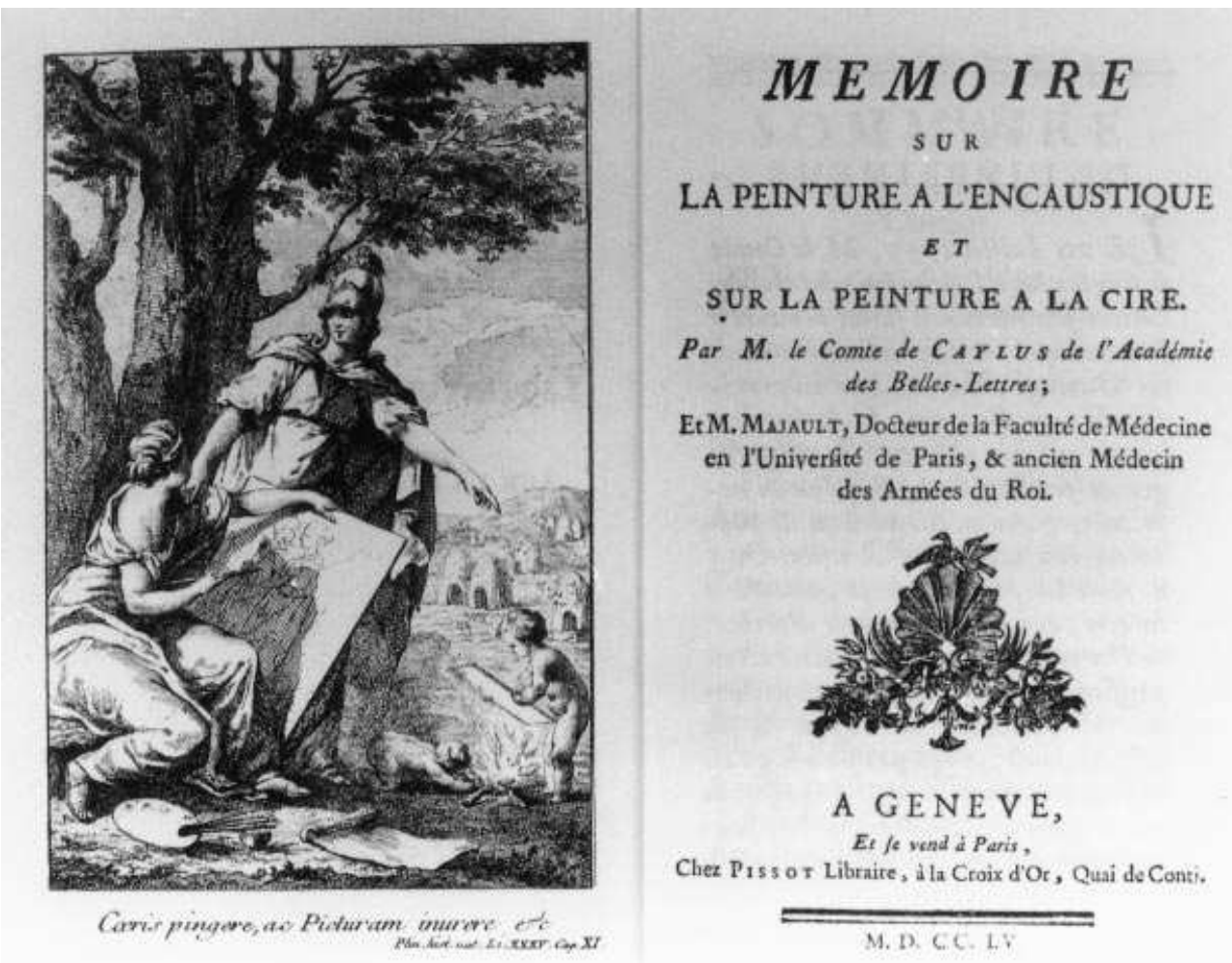

Figure 1. A.-C.-P. de Caylus, Mémoire sur la peinture à l'encaustique et sur la peinture en cire, Puteaux, 1999, reprint of the 1st edition of 1755, front page and Plate 1.

connections between arts and trades. In the frontispiece (Figure 1), Athena was teaching a muse how to heat the painting, enhancing the antique reference and the narrative of invention as a product of genius and divine inspiration, like painting. Technology had to deal with fine arts and that meant more pride for inventors and for artists. As a matter of fact, at the end of the book (Figure 2), the tools and apparatus for melting upon fire were described in the rational way of the technical drawings of the Académie des sciences. In Caylus's mind, art was relying on the knowledge of technical devices and on the study of models from antiquity; reusing the ancients' technology meant even more glory for the artist. ${ }^{29}$

Did these exchanges entitle inventors to lay claim to such glory as artists? In a symmetrical way, was it legitimate for an artist to seek recognition through technical invention? For Diderot, surely not; there were limits, boundaries, because technical invention did not rely on genius but on method. It did not have much to do with subjectivity, hence with personal exceptionality and private property. Considering the material side of art, encouraging technical and scientific research in art should not bring any reputation to artists. Their glory was somewhere else, not in the material, organic part

29 Pomian, op. cit. (20), 155-7. 


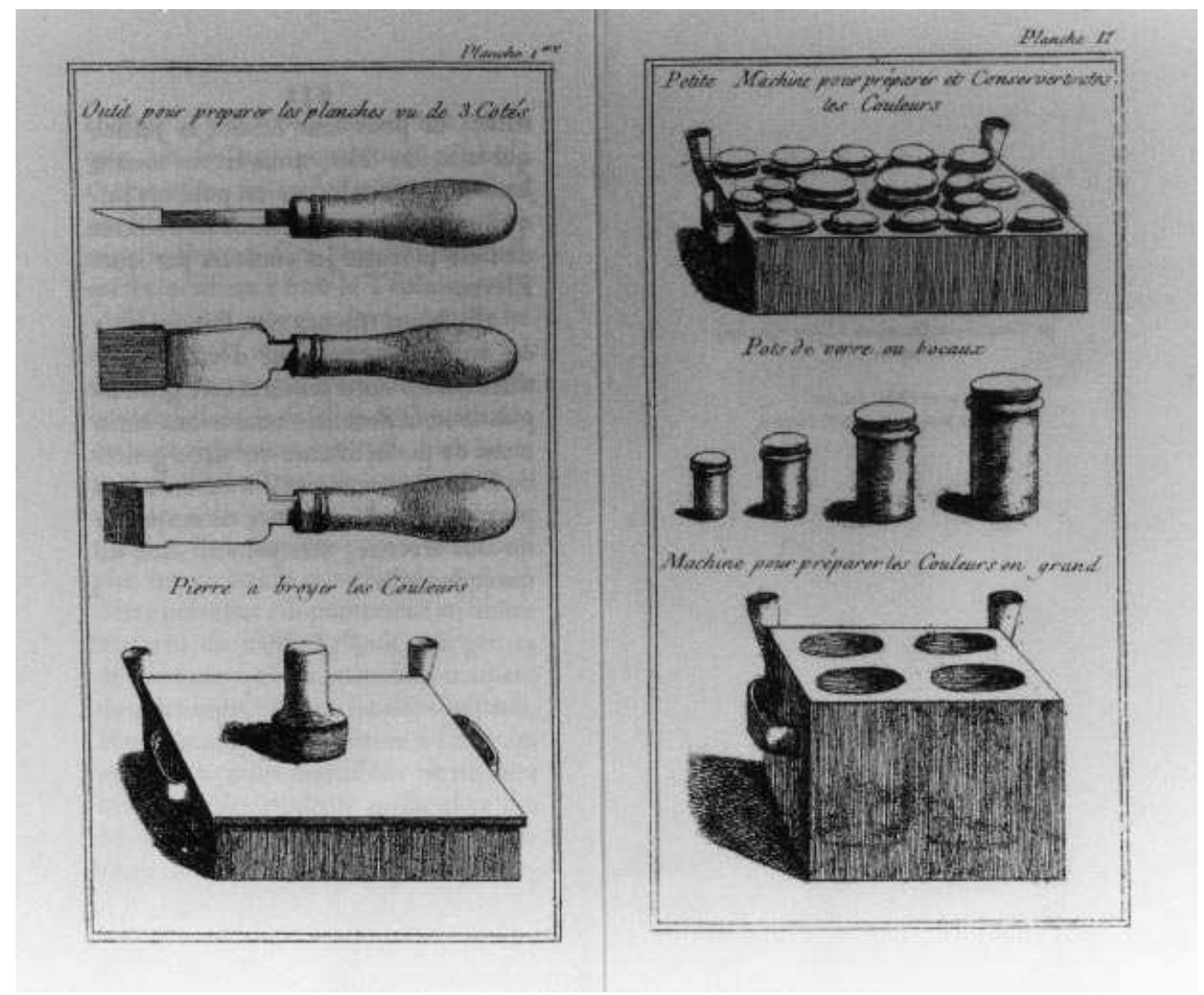

Figure 2. A.-C.-P. de Caylus, Mémoire sur la peinture à l'encaustique et sur la peinture en cire, Puteaux, 1999, reprint of the 1st edition of 1755, Plate 2.

of the painting which appealed to the senses, as Kate Scott has demonstrated. It relied on the genius of the painter, who created such an illusion that his work recreated nature by means of perspective, volume, light and depth. ${ }^{30}$ The value of encaustic varnish for Diderot was precisely in avoiding reflections on the surface of the painting, it was in helping to revive the illusion of imitation, the art of colours, not only of drawing at the surface of the picture. Diderot was enthusiastic for encaustic because this technique would reveal the artist's genius and perpetuate it for posterity thanks to better conservation of artefacts. What imitation meant in art and trades was at the heart of the controversy.

Diderot and the art of invention: collection, imitation, translation

Both Diderot's text and the whole affair revealed eighteenth-century conceptions of invention: it was based on gathering facts, collecting, rediscovering and borrowing. In that perspective, there was no crude opposition between Diderot and Caylus. Nevertheless there was a limit, as Diderot clearly indicated.

30 See also Heinich, Du Peintre, op. cit. (6), 171-7 ('De la règle au génie') and Chapters 6 and 7. 
For Diderot and Caylus, inventing meant discovering and adapting. The inventor was a medium, a translator. The exact wording and good translation of antique texts were at the heart of the controversy. Diderot denied that Caylus had rediscovered Pliny's authentic method. The experiments in Caylus's treatise were presented as tests for explaining the ancient text: 'Au reste il est constant que l'on peut donner des sens différens au passage de Pline, et tous ceux dont il est susceptible nous ont fourni le sujet des autres manières de peindre dont nous allons faire le détail' ${ }^{31}$ One of Caylus's discussions, for instance, was the distinction between two Latin words, 'urere' and 'inurere', one for the melting process on fire, the other for the heating of the painting afterwards, to fix the colours, which actually was 'encaustic painting' according to him. This permitted him to define what 'encaustic' meant, to clarify its difference from mere wax painting and to combine both processes in a range of inventions. The translation was a path to recollect forgotten memory, buried techniques lying in the opacity of the treatises of the ancients who were deemed to have discovered everything. Transcribing their heritage was the first step to invention. In a second stage, the translation opened the way to imitation and transposition, in search of present utility. Recollecting and comparing were the main processes of invention. Caylus wanted to find out ('deviner') the authentic method of the ancients, and his search in Greek painting was also an occasion for him to try other processes using turpentine, either for colours, or for pure wax or for varnishes.

This method was similar to the archaeological analysis of ancient remains that was Caylus's highest achievement: collecting numerous modest objects, gathering pieces and fragments, for embracing in one scope hints of the whole productive process and of the functionality of the objects. ${ }^{32}$ The collection as a range had the cognitive function of discovering technical operations, functions and uses which might have run from one material to another, from one trade to another. ${ }^{33}$ It revealed technical processes and it offered a method for inventing, through analogy and connections.

31 'By the way, it is clear that different meanings can be given to Pliny's passage, and all these different meanings have provided us the subjects of the several other ways of painting which we are going to describe in detail'. Caylus, op. cit. (22), 48.

32 Schnapp, op. cit. (19); J. Guillerme, 'Caylus "technologue”: note sur les commencements problématiques d'une discipline', Revue de l'Art (1983), 60, 47-50.

33 B. Jacomy, 'Le Musée des arts et métiers: un musée de prototypes', in Pratiques historiques de l'innovation historicité de l'économie des savoirs, XVe-XXe siècle (ed. L. Hilaire-Pérez and A.-F. Garçon), conference of the CNAM, 21-3 March 2000), forthcoming; J. Guillerme (ed.), Les collections. Fables et programmes, Seyssel, 1993, Chapter 5; L. Dolza and H. Vérin, 'Enigmes et raisons des théâtres de machines de la Renaissance', Paris, forthcoming; H. Vérin, 'Les machines hydrauliques dans les théâtres de machines (XVIe-XVIIe siècle)', in Archives, objets et images des constructions de l'eau du Moyen Âge à l'ère industrielle (ed. L. Hilaire-Pérez, D. Massounie and V. Serna), Conference of the CNAM, 7-9 December 1999, forthcoming in April 2002, Lyon; L. Hilaire-Pérez, 'Les dépôts d'invention en France et en Angleterre au XVIIIe siècle', in Des matériaux pour l'histoire. Archives et collections scientifiques et techniques du XVIIle à nos jours (ed. P. Bret, L. Hilaire-Pérez and C. Demeuleanere-Douyère), 2000, 25-37; idem, 'Les boutiques d'inventeurs à Londres et à Paris au XVIIIe siècle: jeux de l'enchantement et de la raison citoyenne', in La Boutique et la ville. Commerces, commerçants, espaces et clientèles XVIe-XXe siècle (ed. N. Coquery), Tours, 2000, 171-89. The English archaeologist Daniel Lysons collected advertisements for inventions and set them up in a new order, ranged by commercial and productive sectors, suggesting networks and relationships in invention which could not appear so easily by the regular reading of newspapers. 
Translation from Latin and collection of artefacts were metaphors for actual transpositions. These transversal networks were at the heart of both Caylus's and Diderot's texts. Caylus explained how he borrowed techniques from cabinet-makers (to make the wax enter the wood support for the Head of Minerva), how he used the same 'résines' ('resins') as that used for small candles ('pour imiter la cire de ces bougies' ${ }^{34}$ ). Diderot also mentioned that the use of turpentine with colours was well known for calicos, for 'transparents' and for medicinal balsams ('cérats') but it had been transposed to the mixing of colours, instead of traditional linseed oil. The same for alkaline solution with wax: soap was currently used but its properties were transposed for replacing oil by ean de cire (wax water) in the preparations of colours. Very similar was his description of the new encaustic pastel technique necessitating the use of an enamel-making furnace (Diderot wrote for the same volume of the Encyclopédie the article on 'Enamel'). He also recommended encaustic paint for ceilings, panelling and the making of 'similor' (imitation of gold); he asked Bachelier in a note to confirm this last idea by experiment. Invention required collaboration.

Diderot's general theory was that inventing meant discovering the relations between facts in the world of nature and in the world of arts; there existed 'liaisons' ('links'), analogies and echoes between trades; but men were often too distant to discover the 'rapports utiles et ignorés' ('useful and unknown connections'), which was a fundamental notion for the building up of technology as the science of technical purposes, designs and projects running across the different trades, as Johann Beckmann would systematize it one generation later. ${ }^{35}$ In this field, Diderot's, Bachelier's and Caylus's approaches were very close to each other. ${ }^{36}$ Diderot explained that particular operations should not be limited to one kind of workshop, that workers should compare trades and give each other mutual help. They should work in common, in a complementary perspective, around the same table, possibly in an academy under the protection of a 'monarque artisan':

Combien de découvertes qui se touchent dans la nature et dans les arts, et que de grands intervalles séparent dans la durée et dans l'entendement? Elles attendent quelque évènement futile, comme la chute d'un bout de bougie dans un godet, la rencontre d'un passage de Pline pour éclore et faire dire aux sots: Quoi, ce n'est que cela? Pour laisser moins d'ouvrage au hasard, il n'y aurait qu'à rapprocher les connaissances. Qu'importe que la nature ait mis tant de liaison entre les arts, si quelque grande institution n'en met pas davantage entre les différents artistes? Rien ne devrait être plus commun, et rien cependant n'est plus rare que le passage d'un manœuvre d'un atelier dans un autre.... Quels secours mutuels les arts mécaniques ne se prêteront-ils donc pas, si jamais la volonté bienfaisante d'un monarque artisan les rassemble dans une académie? Quelle immense quantité de rapports utiles et ignorés, qui se manifesteront à la fois et qu'on n'apercevra que lentement, par hasard et successivement, tant que les objets écartés les uns des autres ne seront

34 'To imitate the wax of these candles'. Caylus, op. cit. (22), 75.

35 J.-L. Le Moigne et H. Vérin, 'Sur le processus d'autonomisation des sciences du génie', De la Technique à la technologie, Cahiers S.T.S., (1984), 2, 42-55.

36 Bachelier thought that teaching technology meant teaching the connections between trades, whatever the shapes and the materials, and that the combining of these relations would train the pupils' inventivity; see Deforge, op. cit. (17), 172; for Caylus and technology, see Guillerme, op. cit. (32). A very similar appropach is to be found in Campbell's guide, describing trades through their common operations: R. Campbell, The London Tradesman, New York, 1969 (1st edition 1747); see L. Hilaire-Pérez, 'Cultures techniques et pratiques de l'échange. Inventions, réseaux et négociations entre Lyon et le Levant au XVIIIe siècle', Revue d'Histoire Moderne et Contemporaine, forthcoming in April 2002. 
point à portée d'être comparés, et que certains hommes qui ... se sont rempli la tête de phénomènes et de faits, ne se trouveront point assis les uns à côté des autres, les coudes appuyés sur une même table, et dans le cas de deviser entre eux librement. ${ }^{37}$

We see that the academic system, inherited from the Renaissance and Bacon (model of the Encyclopédie), was not an archaic and absolutist reminiscence. Diderot could praise it as a means for favouring technical progress because Parisian and provincial academies were actually one basis for encouraging invention in eighteenth-century France. The Paris Académie des sciences was the masterpiece of an administrative system rewarding inventors for the utility of their inventions and the service they offered the nation. The academicians examined the inventions, calling experts from trades and from local institutions to judge the efficiency of the invention; some academicians also visited inventors' workshops and others helped in the management of royal manufacturies. The Paris Academy published records of rewarded inventions all through the century. ${ }^{38}$ The examinations were tests and they even allowed improvements and adaptations. Inventing through cooperation was the aim of the academic system and it was a widely shared principle, also in institutions competing with the Académie des sciences, like the Société des arts de Paris (1718-36) and the attempt at an Académie d'horlogerie (1746). This latter was described in the article on 'Watchmaking' of the Encyclopédie by Jean-Baptiste Le Roy, who thought, like Diderot, that 'les arts ne se perfectionnent que par le concours de plusieurs personnes qui traitent le même objet' 39 (and that invention was an illusion: 'le public imagine que l'art se perfectionne, tandis qu'il ne fait que revenir sur ses pas en tournant comme un cercle. On prend pour neuf tout ce que l'on n'a pas encore vîu $\left.{ }^{40}\right)$.

Such exchanges in trades could also be beneficial to artistic creation. Diderot thought that encaustic paint and the use of wax pastels contrived by Bachelier could facilitate the corrections of the painter. Artistic practice itself relied on improvement, on learning, on adapting 'existing designs', ${ }^{41}$ on self-copy and on repentirs. ${ }^{42}$ There was a method in art

37 How many discoveries which are so close to each other in nature and in arts, and which are so distant in time and in understanding? They are waiting for some trifling event, like the fall of a piece of candle in a saucer, the encounter of a passage from Pliny, to burst out and to make fools say: What, it was nothing else? What does it matter if nature has set so many links between arts, if some great institution does not set some more between the different artists? Nothing should be more usual, though it is so rare, as the passing through of workers from one workshop to another. ... How great the mutual help betweeen the arts, if ever the will of a monarch artisan gather them in an academy? How vast the number of useful and unknown connections, which will show themselves all together and which will only be slowly discovered, by chance and one after the other, as long as the separated objects will not be within scope of comparison, and as long as some men who ... have filled up their heads with phenomena and facts, will not be found sitting each one close to the other, resting their elbows on the same table, and able to exchange views freely.

Diderot, op. cit. (3), 811 .

38 Jean-Gaffin Gallon (ed.), Machines et inventions approuvées par l'Académie royale des sciences depuis son établissement jusqu'à présent; avec leur description, 7 vols., Paris, 1735-77; Recueil des pièces qui ont remporté les prix de l'Académie 1720-1772, 9 vols., Paris, 1721-77; Histoire de l'Académie royale des sciences, avec les Mémoires de mathématique et de physique. Tirés des registres de cette Académie (1699-1790), 92 vols., Paris, 1702-90.

39 'The arts only improve through the cooperation of several persons who deal with the same object'.

40 ' $[\mathrm{T}]$ he public supposes that art can improve, although it only retraces its steps by turning round like in a circle. We consider as a new thing whatever we have not yet seen'.

41 See, for instance, Miller, op. cit. (11), 163-4.

42 See K. Scott, 'Chardin multiplié', in Chardin (catalogue of exhibition), Paris, 1999, 61-73 
creation which was not so far from technical invention. Copying and imitating were also the basis of artistic practice and even the ground of aesthetic classical theory and taste. Did this mean that artistic and technical activities were of the same stuff? How far could boundaries blur between art and trades? What was the issue for self-distinction and property rights?

The question was important as some painters and theoreticians of art were aiming to build up artists' social status by refusing the link with methods and rules and by opposing the idea that art should be learned through the imitation of models, side by side with teachers (as in Bachelier's design school, where pupils were compelled to copy models thanks to numerous engravings and to individualized teaching). ${ }^{43}$ They wanted the artist to separate from guilds and crafts (which provided art education strongly based upon imitation, as in the Lyonnaise silk industry) and to give a new meaning to the word 'artist', which was so ambiguous in the ancien régime. ${ }^{44}$ The academism and the classicism as a set of rules and norms were their second target. ${ }^{45}$ Amateurs like Caylus were also opposed as they grounded artistic practice on study, knowledge, reason and technical devices, much more than on emotion and genius. ${ }^{46}$ Opponents like Diderot claimed artists' individual and innate genius; their model could only be nature itself (the present, not the past), which artists could reveal and recreate through their art, as Chardin did (whom Caylus and his friends despised so much). ${ }^{47}$ This should be the ground for artistic creativity. The notion of imitation was no longer associated with the 'technical virtuosity of mimesis' inherited from the culture of curiosity and traditionally opposed to invention as a historical narrative itself learnt by imitating academic models. ${ }^{48}$ The relationship between imitation and invention, the basis of painting since Roger de Piles, was now opening the door to the subjectivity of the artist. ${ }^{49}$ Imitation meant unveiling and reproducing nature thanks to the artist's imagination and emotion. This led artists to claim that their works were original expressions of their selves and should not be judged by their contemporaries, only by posterity. Human law was not theirs; they had a natural right to their works.

\footnotetext{
43 Deforge, op. cit. (17), 171; A. Becq, Genèse de l'esthétique française moderne 1680-1814, Paris, 1994 (1st edition 1984), 589-646.

44 Becq, op. cit. (43), 756-7; Heinich, 'De l'Apparition', op. cit. (6).

45 F. Waquet, 'La Bastille académique', in La Carmagnole des muses. L'Homme de lettres et l'artiste dans la Révolution (ed. Jean-Claude Bonnet), Paris, 1988, 19-35; A. Picon, Architectes et ingénieurs au siècle des Lumieres, Marseille, 1988, 90-1, 231-40.

46 Pomian, op. cit. (20), 156.

47 K. Pomian, 'Maffei et Caylus', in idem, Collectionneurs, amateurs et curieux. Paris-Venise: XVIe-XVIIIe siècle, Paris, 1987 (1st edition 1978), 195-211, 199; Becq, op. cit. (43), 610-12; Becq, op. cit. (12); Démoris, op. cit. (12); R. Démoris, 'Chardin et les au-delà de l'illusion', in Chardin, op. cit. (42), 99-109.

48 L. Daston and K. Park, Wonders and the Order of Nature, 1150-1750, New York, 1998, 276-301.

49 Becq, op. cit. (43), 607-46, 642; Becq, op. cit. (12). For Chardin, excelling in painting still-life and everyday scenes, even imitations of paintings were not considered as mere copies, they were always different, singular artefacts. See Scott, op. cit. (42). K. Scott, in 'Crimes d'imitation: le portrait et les droits d'auteur en France sous l'Ancien Régime', paper presented at the Collège de France, seminar of Daniel Roche, 10 December 2001, also shows the evolution of the painting of portraits with the growing praise of the artist's genius challenging the virtuosity to reproduce nature exactly. In another way, for Adam Smith, the pleasure created by imitation relied on the gap between the natural model and the artefact. See A. Smith, Essais esthétiques. L'imitation dans les arts et autres textes, Paris, 1997, 41-83.
} 
Diderot was not distant from such a conception. Even if he praised technical invention and could consider machines works of art (both producing effects), ${ }^{50}$ he also tried to distinguish between the artists' and the inventors' processes of invention and between their respective claims to fame. Danielle Rice has insisted on Diderot's shift against Bachelier after the controversy with Caylus had reached its climax. Rice argues that Bachelier and Caylus were quite close to each other and that Diderot in fact opposed both. In dispute was the conception of art as the expression of genius and of self or as the expression of a method, of rules and especially of models imitated.

The question rested, then, on the meaning of imitation. Though in 1755 Diderot was not so explicit on the question, the salons, from 1759, the Essai sur la peinture (1765) and then the Pensées détachées sur la peinture (1776) were quite clear about his rejection of academic style, his opposition to the predominance of drawing in the training of the painters and his glorification of the artist's genius. There was a link with the pamphlet on encaustic, where he appreciated the encaustic technique because it gave access to the depth of the painting and to the genius of the painter, which also would be kept for posterity thanks to the quality of encaustic.

Bachelier and Caylus also praised the non-shining effect of the encausting paint as a way to evince rococo style and to give rest to the eye ${ }^{51}$ which was close to Diderot's complaint about 'contortions' when looking at shiny and greasy paintings inside heavy golden frames. But the three theoreticians disagreed on one point. According to Danielle Rice, Bachelier and Caylus thought that the complex technique of encaustic would lead artists to more discipline, to contain the impetuosity of their genius (in Bachelier's design school geometry was fundamental; it aimed at 'stopping the flights of fancy, at restraining imagination within the bounds of reason').52 For Caylus, promoting archaeological research as an antiquarian and an amateur, studying the ancients' works of art and technical devices should be the first duty of any artist. ${ }^{53}$ On the contrary, Diderot, like Hogarth, ${ }^{54}$ feared rules, models, history paintings and classicism, the dogma of an academic hierarchy of genres. ${ }^{55}$ The question was to escape from the surface of the painting, from the place of the drawing and of the narrative. Imitating antiques enhanced geometry and the drawing of shapes and lines, as in Wedgwood cameos and potteries (the English manufacturer patented encaustic paint in 1769). This linked art to cognition, not to nature and to emotion.

Using encaustic paint did not mean the same for Diderot and Bachelier, Caylus and Wedgwood; for Diderot, intertwining art and industry, even showing the material and manual side of art, did not entail that in creativity art was to follow the path of technical inventivity. In the salon of 1759, Diderot criticized both Caylus's and Bachelier's new

50 Damisch, op. cit. (12).

51 Bachelier introduced this sober taste in the Sèvres production with biscuitware. T. Préaud, 'Jean-Jacques Bachelier à la Manufacture de Vincennes-Sèvres', in Jean-Jacques Bachelier (1724-1806), peintre du roi et de Madame de Pompadour, Paris/Versailles, 1999, 51-65.

52 Deforge, op. cit. (17), 271.

53 Becq, op. cit. (43), 517; Pomian, op. cit. (47), 200.

54 Berg, 'From imitation', op. cit. (14).

55 R. Michel, 'Diderot et la modernité', in Diderot et l'art de Boucher à David. Les salons: 1769-1781, Paris, 1984, 110-21. 
paintings and argued that 'tous ces chercheurs de méthodes nouvelles n'ont point de génie' ${ }^{56}$ There was a limit to the transposing of technical methods in art. The principles of imitation, copying and borrowing did not lead to the same issues in art and in trades; in the one case, individual genius, artist's nature were at stake; in the other, invention was a collective and social process based upon cooperation, training and exchange. Diderot wished to reopen the question. One way was to write theoretical essays in aesthetics; another was to launch pamphlets against artists pretending to self-glorification through technical prowess, a petty project for Diderot. Did it mean that inventors had no right to property, to fame and to distinction? The pamphlet addressed a much-debated question: the value of inventions and the social credit of inventors.

\section{Invention and reputation: the moral economy of invention}

For Diderot, there was something vain and low in claiming any right to invention; the method of invention contradicted any appropriation. Such an opposition was not only grounded on Baconian praise for collective research; it was also a reaction to strong pressures coming from trades and markets at the beginning of the eighteenth century. Private interest and business culture and practices, even speculation, were very much linked to technical inventions. ${ }^{57}$ Distorting values, imitating and copying, usurping credit and seducing public trust and resources were the core of projectors' activity, both in France and in England. Inventing had to deal with the way credit and trust were invested and circulated. Art was much involved in this speculative technical trend. The evolution was considered a threat to the progress of trade and to the perfection of art. The questions were: who was entitled to set the value of inventions? Which rhetoric was legitimate? Diderot had precise answers.

Diderot's insistence upon the necessity of an academic frame for collective invention expressed a lack of trust in market-based collaborations and, more generally speaking, some fear that market forces could be inefficient and even bring loss of techniques if they were not profitable enough for investors. The exchanges between trades were too limited, not only by the boundaries between guilds, but also by private interests in inventions. This latter aspect was the main problem for Diderot as for the encyclopaedist watchmaker Le Roy. Their ideal of collective institutions and the public utility of inventions was an answer to the very active market for inventions that had developed at the beginning of the eighteenth century.

Both in France and in England, this was a period of projects, schemes and speculations. Inventions were much involved in this movement, especially when they were protected by exclusive rights: patents in England and exclusive privileges in France. As invention was so close to copying and borrowing, inventors were tempted to protect against rival imitators. ${ }^{58}$ Patents were also used in other ways, more 'heterodox' (in the words of

56 'All these researchers of new methods have no genius'. Salons de 1759, 1731, 1763, Paris, 1984, 99.

57 C. MacLeod, 'The 1690s patents boom: invention or stock-jobbing?', Economic History Review (1986), 39, 549-71; L. Stewart, The Rise of Public Science: Rhetoric, Technology, and Natural Philosophy in Newtonian Britain, 1660-1750, Cambridge, 1992, Chapters 4, 7, 8, 9; L. Hilaire-Pérez, 'Transferts technologiques, droit et territoire: le cas franco-anglais au XVIIIe siècle', Revue d'Histoire Moderne et Contemporaine (1997), 44, 547-79. 58 Berg, 'From imitation', op. cit. (14). 
Christine MacLeod). They were at the heart of two speculative waves, in the 1690s and in the 1710s, attracting credit and ruining some investors like Daniel Defoe, who wrote $A n$ Essay Upon Projects in 1697 to denounce the way that patents could lure public trust. Defoe urged the setting up of academies which would tell the truth about inventions, establish the value of inventions according to their public utility and reward the inventors. The scientific institution was considered a barrier against speculation on invention and some members of the Royal Society of London actually tried to develop expertise in projects. Throughout the eighteenth century, the question of credibility for new technical schemes was at the heart of debates about the social benefits of public science (experiments, conferences, shows) and the risk lying in the 'manipulation of the market'. ${ }^{59}$

In France too, the beginning of the century was a time of both financial speculation and bursts of technical projects. The best example of these links between business and technical devices is the part played by John Law, who encouraged financial investment and industrial transfers from England. ${ }^{60}$ The economy was opening to risk, to accelerated circulations and to subversion of values. ${ }^{61}$ This was emphasized by the development of a consumer society. Claims for exclusivity, for novelty, for secrecy, for priority, for academic approval and for utility were all instrumentalized by dealers competing by enhancing their reputation among the public. ${ }^{62}$ This was part of their know-how for selling new products by offering the customers the illusion of distinction through consumption. Appearances, displays and rhetorical strategies were transforming the relationships between retailers and customers. Invention was involved in a huge destabilization of values, references and norms in the world of trades. The part of imitation in invention meant plagiarism, usurpation, faking, cheating and 'false work', and it boosted reputations. It was offensive, subversive and mercantile. Exclusive privileges for inventions reinforced the evolution. They were used to fuel ventures, to set up transactions and obtain credit, to build up enterprises in partnership which could be ephemeral. Inventions and exclusive titles were appropriated by whole familial networks and sold as shares of capital. ${ }^{63}$ Public benefit in technical projects was often far removed from strategies based upon exclusivity.

The Histoire et secret de la peinture en cire mocked reputations and transactions built upon the seductive side of new technical devices. Diderot's praise of Bachelier was in fact quite ironical. He recorded that Bachelier had sold the encaustic secret for an important

59 L. Stewart, 'A meaning for machines: modernity, utility, and the eighteenth-century British public', Journal of Modern History (1998), 70, 259-94; Simon Schaffer, 'The consuming flame: electrical showmen and tory mystics in the world of goods', Consumption and the World of Goods (ed. J. Brewer and R. Porter), London, 1993, 489-526; idem, 'The show that never ends: perpetual motion in the early eighteenth century', BJHS (1995), 28, 157-89.

60 J. R. Harris, Industrial Espionage and Technology Transfer. Britain and France in the 18th Century, Aldershot, 1998, Chapters 1 and 2.

61 J.-Y. Grenier, L'économie d'Ancien Régime. Un monde de l'échange et de l'incertitude, Paris, 1996, 252-5, 325-31, 420-1; F. Freundlich, Le Monde du jeu à Paris, 1715-1800, Paris, 1995, 17-21, 57-189, 169-82, 203-33, 244.

62 N. Coquery, 'Mode, commerce, innovation; la boutique parisienne au XVIIIe siècle', in Pratiques historiques de l'innovation historicité de l'économie des savoirs, XVe-XXe siècle (ed. L. Hilaire-Pérez and A.-F. Garçon), conference of the CNAM, 21-3 March 2000), forthcoming.

63 M. Sonenscher, Work and Wages: Natural Law, Politics and the Eighteenth-Century French Trades, Cambridge, 1989, 210-43; Hilaire-Pérez, op. cit (10), 115-24. 
sum to a goldsmith and colour-maker, Jean-Claude Odiot, a member of a wealthy and famous family in the luxury trades. The disclosure of the process was a threat to Odiot's benefit as an exclusive user of Bachelier's invention. He was also bringing Bachelier into a difficult position: 'Je ne doute point que M. Bachelier ne me sache manvais gré de publier un secret dont il pouvait avec raison promettre quelque avantage ... mais j'ai mon caractère ... ${ }^{64}$ Diderot was clearly denouncing the transactions made with technical inventions: 'je n'ai promis de secret à personne; je ne suis retenu par aucune de ces conventions qu'il est honnête de tenir, et je suis sollicité par une de ces vues générales auxquelles il serait déshonnête de résister ${ }^{2}{ }^{65}$ The Année littéraire actually recorded in 1755 that Odiot asked Bachelier to reimburse the sum he had invested for the secret and that Bachelier refused, arguing that Diderot had not asked him if he could publish the secret. ${ }^{66}$

Bachelier was much involved in luxury trades and in the growing specialized retail trade in supplies for painting $;^{67}$ he was active in selling pieces from the Sèvres manufactury with the help of a relative who was a mercer (marchande de modes). ${ }^{68}$ Marketing novelties and seeking fame through invention and exclusivity were part of Bachelier's world. Reputation as an artist and reputation as an inventor could help each other. In a similar way to Wedgwood in England, he was using artistic design, patents and the aristocratic market to build up his reputation and his commercial success. According to Diderot, this evolution was a real threat for art and artists. The whole antique style was not only academic but it was also a successful fashion in Europe. It was a style open to market strategies, secrecy, patents and material perceptions of art. Imitating the ancients encouraged both the methodical side of painting and the organical approach of art (Kate Scott). An artist claiming any pride in technical invention was not only ridiculous, he was subversive and somewhat destructive, at least for Diderot. In the realm of art, denouncing secrecy, privileges and commercial reputation enhanced the defence of art as an illusion and as an intimate exchange with the viewer. For Diderot, respect for the works and for the public sensibility was precisely enhanced by encaustic varnish which preserved paintings from aggressive and gaudy restorations of surfaces ${ }^{69}$ Diderot's pamphlet, opposing these evolutions, was part of a general attempt to redefine the morality of art and trades.

Since the 1720s there had been growing opposition to the marketing of inventions and privileges. Diderot's denunciation of 'conventions' as opposed to the morality of disclosure for public good illustrated a more general tendency. Guilds set up law suits

64 'I do not doubt that M. Bachelier will be annoyed with me for publishing a secret with which he could reasonably promise some advantage ... but it is my nature ...'. Diderot, op. cit. (3), 809.

65 'I have not promised the secret to anybody; I am not bound by any of these agreements honestly set up, and I am moved by one of these great aims which it would be dishonest to resist'.

66 Rice, 'Jean-Jacques Bachelier', op. cit. (4), 74 n.

67 I. C. Bristow, 'Paint. II. Manufacture and trade' in Dictionary of Art (ed. Jane Turner), New York, 1996, 785-6; P. Labreuche, 'La toile à peindre à Paris aux XVIIIe et XIXe siècles. Techniques de préparation', DEA report, Paris, CNAM-EHESS, 2000.

68 Préaud, op. cit. (51).

69 Actually, Gautier d'Agoty, painter, anatomist publisher, plagiarist and privileged entrepreneur in printing trichromy, contrived devices to substitute technical processes for the hand of the painter and advised very aggressive treatments for restoring paintings, by a sort of unskinning of the surface of the painting, like an anatomical operation; Lavezzi, op. cit. (7). 
against projectors on the grounds that public utility was neglected by their investors. The quest for authenticity by reference to antiquity was also one attempt to set anew the value of inventions outside the business world. There was a general urge to moralize technical invention, to create rules for ascertaining credit in invention and to castigate unscrupulous dealers. Humanity should not be deprived of useful knowledge because of the uncertainties of the market and of the private interests of the makers and retailers. Exclusive privileges were focusing the critics. ${ }^{70}$ The governmental administrators rejected them as a means of abusing credulous investors. The disclosing and disseminating virtues of exclusivity were less and less obvious. They were a threat to the common good and it was argued they contradicted the traditional conception of natural right as a common right to work and to possess. Nobody possessed any private right to invention and refusing to disclose a technical process was a theft to humanity, as Diderot wrote:

Nous existons d'une existence si ignorante, si courte, et si malheureuse, que l'ecclésiastique avare de son argent et le philosophe avare de ses découvertes, font tous les deux un vol aux pauvres. D'ailleurs, les découvertes ne me paraissent en valeur et en sûreté, que quand elles sont rentrées dans la masse commune, et je me hâte de les y porter. ${ }^{71}$

The only honest theft was to deprive the inventor of his secrets. Diderot was ironically apologizing for stealing Bachelier ('l'espèce de vol que nous lui faisons'). This idea of a necessary theft of inventions for public good was expressed by other members of the enlightened elite at the same time, like the Lyonnaise artist and inventor Philippe de Lasalle, encouraging the circulations of all novelties, even by copying and stealing inventions. Disclosure of new techniques could only be achieved by the denial of inventors' private property. There was no longer any trust in the efficacy of exclusive rights. The only private advantage an inventor could pretend to would be a reward based on a close examination of public utility. Reputation in invention should not match commercial interest; it had to derive from official evaluation and to be based upon common good. ${ }^{72}$

Academicians were traditionally requested by the government to determine the official value of inventions. As they were invested with royal authority, their involvement was crucial for crediting inventions. Examinations were spectacular shows relying on the credit of the witnesses. ${ }^{73}$ The enlightened administrators extended this procedure to the determination of economic utility. In their reforming schemes, invention was a tool for rationalizing and modernizing some industries (wool, silk, cotton, chemistry, small metallurgy and steel). It was a privileged instrument for political action. Indeed, academicians had never been so much involved in expertise (some even entered the government as full-time experts) but their examinations entailed complex negotiations between scientists, administrators, other technical experts, members of guilds and officials

70 Diderot's article on 'Brass' (laiton) in the Encyclopédie clearly opposed public good and exclusive rights. 71 'We exist within such an existence so ignorant, so short, and so sad, that the vicar sparing his money and the philosopher sparing his discoveries, both steal from the poor. Besides, I think that discoveries are safe and valuable, only when they have come into common knowledge, and I hurry to bring them in'. Diderot, op. cit. (3), 809-10.

72 Hilaire-Pérez, op. cit. (10), 70-82, 124-44.

73 C. Licoppe, La formation de la pratique scientifique. Le discours de l'expérience en France et en Angleterre (1630-1820), Paris, 1996, Chapters 3, 5; R. Hahn, The Anatomy of a Scientific Institution: The Paris Academy of Sciences, 1666-1803, Berkeley, 1971, Chapter 5. 
of local institutions. The academic judgement of authority expanded to judgements of facts and opinions. Technical efficiency was related to the possible uses of the inventions by the public, producers, consumers, administrators and subjects. Collective evaluation and public good became the reference points for determining the qualities and advantages of inventions.

Rewards, either the few exclusive privileges or the numerous financial grants, would embody these negotiations. This was also the core of the royal declaration of 24 December 1762, grounding privileges on utility and merit; establishing priority was not even mentioned in the law (and it was not so crucial for Diderot ${ }^{74}$ ). Privilege was the price of the service; it was cautiously bestowed by administrators questioning the economic utility of exclusivity for the nation, not for the entrepreneur. The exclusive privilege had to be put in operation (not used in transactions) and inventors had to teach their knowledge according to the governmental plans. The exclusive right could be complemented by several other rewards, either national or local (fiscal exemptions, honorific awards, financial grants and bounties indexed to the output, to the spread of the invention or to the number of apprentices taught the new technique). The traditional meaning of exclusivity (a contract between the inventor agreeing to share and spread his knowledge and the state, protecting him, as in fifteenth-century Italian cities) was re-emerging, as a means for integrating new technical devices into the common knowledge (the 'masse commune', as Diderot said). ${ }^{75}$ Openness, which was fundamental for enlightened elites, had to be run by the state in order to benefit the whole economy. This was the basis of the expertise, the most important and first step of the procedure.

Before granting a privilege or any other reward, the expertise required disclosure of the invention. Actually, it was not an absolutist practice of censorship (even if academicians were demonstrating their power and authority); the expertise aimed at questioning the efficiency of the invention according to the needs and to the uses of a whole range of trades (who took part in the expertise), of the consumers (who wrote certificates) and of the administrators who developed plans for reforming industry. Every petition was inserted in a complex network including inspectors of manufactures, guilds officials, academicians and members of local boards and of townships. In the enlightened French state, inventors' initiatives were never separated from public good and from the diversity of interests expressed by economic and political actors. The merit of the inventor was a negotiated notion and this collective appraisal of the invention was the basis for restoring the moral

74 If inventing meant discovering 'liaisons' (links) between things, several individuals might simultaneously invent the same device, whatever be the medium, chance or reading of Pliny: 'At the very moment I am writing, there are several persons who are getting close to Mr. Bachelier's secret, then do not be so sorry if I reveal it'. Diderot, op. cit. (3), 810. Diderot argued that Bachelier and Caylus were both in good position for priority as one was the first to make experiments and the other was the first to have shown the product to the public. Priority was an ambiguous notion and could not be useful for ascertaining the attribution of the invention. Diderot thought that all the improvements Bachelier had made were much more valuable than his first insights.

75 M. Belfanti, 'Corporations et patents: deux faces du changement technique dans une économie préindustrielle (Italie du Nord, XVIe-XVIIIe siècle)' in Pratiques historiques de l'innovation historicité de l'économie des savoirs, XVe-XXe siècle (ed. L. Hilaire-Pérez and A.-F. Garçon), conference of the CNAM, 21-3 March 2000), forthcoming; Long, op. cit. (15); idem, 'Invention, secrecy, theft: meaning and context in the study of late medieval technical transmission' in Inventions, Innovations and Espionage: The Diffusion of the Technical Knowledge in Early Modern Europe (ed. M. Belfanti and F. Giusberti), London, 2000. 
economy of invention. The opposition between private and universal advantages ${ }^{76}$ actually issued in a mixed pattern, as private ambitions were recognized to serve public benefit and social cohesion. State regulation and market forces were then in tune. ${ }^{77}$ Such a reformation refounded distinctions and honour in a world where inventing had opened the way to blurring appearances and to usurpations, cheats and disorder.

Diderot echoed the efforts of the reformist administration. His definition of inventors' fame was rooted in the advocacy of disclosure and merit. Openness of knowledge, without exclusive rights, was the best means to get reputation. In a digression of the Histoire et secret de la peinture en cire, he took the example of a secret remedy with mercury: 'On aurait beaucoup plus de confiance en sa préparation mercurielle, si elle était connue; et les malades donneraient naturellement la préférence à l'inventeur sur les autres chirurgiens' ${ }^{78}$ The other means to obtain public credit was excellence, merit as he explained in the paragraph dedicated to Odiot. Odiot should not hope for profit from secrecy or exclusivity but only from his excelling in the making of the encaustic:

Le Sieur Odiot entend très bien la manouvre de l'encaustique de M. Bachelier; il l'a vu opérer; il a lui-même opéré sous yeux; il en a appris le détail d'un grand nombre d'expériences sur la préparation des couleurs; le public sera naturellement porté à lui donner la préférence, si ce genre de peinture prend faveur; ... il ne pourra conserver cette préférence qu'en servant le public et les artistes mieux qu'aucun d'eux ... ${ }^{79}$

This theme was much developed in Le Roy's article on watchmaking. Le Roy denounced merchants, 'false workers' and 'charlatans' who established their fame thanks to their rhetoric and their advertising method, not thanks to public utility and the collective evaluation of their work. He contrasted the skilful and inventive worker recognized by his peers in a technical academy (he was trying to set up an academy for watchmaking), with dealers and workers outside guilds evading the rules of the trade, corrupting the honour of watchmaking, lowering the quality of the products and ruining international trade. In a paradoxical way, encouraging invention meant restoring order and ethics, norms and identities for products and producers. The inventor's esteem did exist and it was based upon the recall of a double tradition, guilds and academies.

There was another paradox. This recognition of merit and service enhanced the links between the inventor and the invention. A process of personal attribution was emerging in the very heart of cumulative and utilitarian approaches to invention. Some inventions were even called by the names of their rewarded inventors. Inventing was gradually departing from discovering; a subjective meaning was recognized. Although Diderot was so eager to stress the collective process of invention, he also contradicted it in the article on 'Eclecticism' (t. V) (1755). Inventions were still considered as discoveries but inventors

76 H. Vérin, La Gloire des ingénieurs. L'Intelligence technique du XVIe au XVIIIe siècle, Paris, 1993, 379-400.

77 S. Meyssonnier, La Balance et l'horloge. La Genèse de la pensée libérale en France au XVIIIe siècle, Montreuil, 1989, Chapters 6, 7.

78 'We would much more trust his quick-silver drug, if we would know it; and sick people would naturally give preference to the inventor rather than to the other surgeons'. Diderot, op. cit. (3), 823.

79 'Sir Odiot knows very well how to perform with Mr. Bachelier's encaustic; he saw him working; he himself worked under his eyes; he learnt from him a great deal of experiments in the preparation of colours; the public will naturally give him preference, if this kind of painting becomes up to date; ... he will only keep this preference by serving the public and the artists better than any of them would do'. Diderot, op. cit. (3), 807. 
were no more interchangeable. Rewarding them was a necessity for avoiding any irremediable loss for humanity:

il est impossible qu'il y en ait deux qui se ressemblent pafaitement; d'où il s'ensuit pour ceux qui savent raisonner, que toutes les fois qu'une découverte utile attachée à la différence spécifique qui distinguoit tel individu de tous les autres et qui le constituoit comme tel, ou n'aura point été faite, ou n'aura point été publiée, elle ne se fera plus; c'est autant de perdu pour le progrès des Sciences et des Arts, et pour le bonheur et la gloire de l'espèce. ${ }^{80}$

In the Pensées sur l'interprétation de la nature (1753), devoted to technical and scientific activities, he explained that there was 'un esprit de divination' ('a spirit of divination') amongst the 'grands manouviers' ('great workers'). These considerations did not lead him to recognize any property right for inventors, unlike authors or artists, in contrast to Le Roy. ${ }^{81}$ But it was breeding an important evolution that was leading artisans to claim they had a distinct self-identity as creators.

Rewards were fostering upward mobility and desire for distinction among artisan members of guilds. Submitting to academic examinations was injurious and it brought conflicts that were the roots of a new meaning of natural right, as the right of the person, whatever human laws. Neither academicians nor artisans' peers would be entitled to judge inventors. Genius, irrationality, possession by transcendant and divine election would invade inventors' petitions. If these arguments were not immediately very successful, both the growing pressure of capitalists in industry and the failure of the credit of the monarchy resulted in a gradual shift. The government changed the rules of examination. In the 1780s, truth no longer meant utility but, on the one hand, determination of novelty and priority and, on the other, proof that the invention entailed no risk to the public, especially to health. The state was recognizing the capacity of producers, investors and customers to set up the value of inventions provided that it offered some security. The reputation of inventions was in the hands of learned and informed citizens, able to judge and choose; it also depended on the resources of the entrepreneurs and on ascertaining rights in law cases. Privileges looked more and more like patents.

\section{Conclusion}

Diderot's Histoire et secret de la peinture en cire revealed much of his thought on technical invention and artistic creation. First, his conception of invention was based on a method that aimed at discovering connections between artefacts, between trades. In this, he was not so far from the archaeologist Caylus. But this did not mean for Diderot that art and trades were bound to the same destiny. Boundaries had to be recognized. The main issue was the status of inventors in society. Because of this conception, Diderot praised collective institutional settings on the academic and Baconian model. Personal glory or private profit

80 'It is impossible that two of them be totally similar; then, for every one who has senses enough, every time a useful discovery bound to the specific difference which distinguishes one individual from the others and which has made him such as he is, either will not have been realized, or will not have been published, it will not happen any more; it will be so much the less for the progress of Sciences and arts, and for the happiness and the glory of mankind'.

81 The members of the Académie d'horlogerie 'would prevent the thefts which are daily perpretated' and inventors would be protected by the deposit of their descriptions in the registers of the academy. 
in invention were denied. Secrecy, pride and exclusivity were mean and ridiculous strategies, especially for artists, as imitation in painting did not involve the same meaning as in technical creativity. These were good reasons for mocking Caylus and even Bachelier.

On a more general level, Diderot was reacting against a strong economic trend at the beginning of the eighteenth century: business in invention, that merchandizing of inventions and exclusive titles, the fostering of speculation, plagiarism, usurped reputations and corruption of public trust. Like enlightened administrators, Diderot wanted to reassess the value of inventions and the social credit of inventors on grounds of public utility expressed in academic scrutiny. It was a huge enterprise of moralization of invention. As a paradox, although invention was then understood as a daily and usual practice (Diderot said 'un assemblage de petits procédés', 'un travail journalier'), this policy bred mythical narratives of invention through the praise of the deserving artisan. Exclusive property in invention was increasingly claimed by inventors, pretending to the same rights as authors and artists, and official evaluation of inventions was firmly opposed.

However exclusivity was debated, it was embedded in the definition of public trust in invention and social credit of inventors. The question inventions raised related to the making of judgements and of choices, to the negotiations of truth, to 'a culture of disagreement and debate', ${ }^{82}$ either in government and academies or in public opinion and investors' minds. Inventors' rights strictly depended on shifts in ways of evaluating inventions. They were the brand marks of the political, economic and social processes of investment, both financial and, more symbolically, in inventions. In that way, technical inventions entered history by means of a complex process of selection originating in the practices and the expectations of the actors.

82 M. Berg and K. Bruland, 'Culture, institutions and technological transitions', in Technological Revolutions in Europe (ed. M. Berg and K. Bruland), London, 1998, 3-16. 